\title{
Perspectives of Infrastructure Project Finance: Intercultural Investment, Connectivity and Trust
}

\author{
C.H. Luttermann \\ Catholic University of Eichstaett-Ingolstadt, Ingolstadt, Germany \\ https://orcid.org/0000-0002-2901-4591
}

\begin{abstract}
Project finance of infrastructure (e.g. exploitation and transportation of natural resources, high speed railways, internet) forms a basis for the peaceful development and the prosperity of nations as well as the transnational community. What is needed are dependable networks in a world in transition, where digitalisation and new powers demand joint action. Particularly in the Eurasian region, from Lisbon to Vladivostok, fields with future prospects are opening up for Russia, Germany and the European Union. We can develop them through investment and cooperation, by building up trust through common rules and sustainable substance. Here, a concept for this is presented for "Intercultural Project Finance": An order of law and business (order of assets; German:Vermoegensordnung), in which state and private actors build up the necessary trust and are able to co-operate and profit transnationally for the good of the common prosperity of all peoples. A key element of a suitable system for the investment of capital (transnational investor protection law) is a sustainable valuation law; this has to be developed and etablished by legal comparison. In the following, relevant aspects for theory and practice which are basic for the actors of infrastructure project finance will be shown, as well as the new initiative of the European Union regarding "Connectivity". Keywords: project finance; infrastructure; intercultural investment; comparative investment law; Germany; European Union; connectivity; Eurasia
\end{abstract}

For citation: Luttermann C.H. Perspectives of infrastructure project finance: Intercultural investment, connectivity and trust. Finansy: teoriya i praktika = Finance: Theory and Pratice. 2019;23(1):27-37. DOI: 10.26794/2587-5671-2019-23-1-27-37

ОРИГИНАЛЬНАЯ СТАТЬЯ

\section{Перспективы финансирования проектов инфраструктуры: инвестиции, взаимодействие и доверие в межкультурном контексте}

Католический университет им. Айхштетт-Ингольштадт, Ингольштадт, Германия https://orcid.org/0000-0002-2901-4591

\begin{abstract}
АННОТАЦИЯ
Финансирование проектов инфраструктуры (например, эксплуатация и транспортировка природных ресурсов, высокоскоростные железные дороги, Интернет) формирует основу для мирного развития и процветания народов разных стран, а также транснационального сообщества. В условиях меняющегося мира, где цифровизация и новые власти требуют совместных действий, необходимы надежные межкультурные связи. В частности, в Евразийском регионе, от Лиссабона до Владивостока, открываются перспективы для России, Германии и Европейского союза. Эти связи можно развивать через инвестиции и сотрудничество, укрепляя доверие с помощью общих правил и стабильного состояния. В статье представлена концепция «Межкультурного финансирования проектов»: регламент бизнеса и права (порядок активов; нем.: Vermoegensordnung), в котором государственные и частные субъекты формируют необходимое доверие и способны сотрудничать и получать прибыль на транснациональном уровне на благо общего процветания всех народов. Ключевым элементом системы, подходящей для инвестирования капитала (закон о защите транснациональных инвесторов), является закон об устойчивой оценке; он должен быть разработан и установлен путем правового сравнения. Показаны соответствующие аспекты теории и практики, которые являются основными для участников финансирования проектов инфраструктуры, а также новая инициатива Европейского союза в отношении межкультурного взаимодействия.

Ключевые слова: проектное финансирование; инфраструктура; межкультурные инвестиции; сравнительное инвестиционное право; Германия; Европейский союз; взаимодействие; Евразия
\end{abstract}

Для цитирования: Luttermann С.Н. Perspectives of infrastructure project finance: Intercultural investment, connectivity and trust. Финансы: теория и практика. 2019;23(1):27-37. DOI: 10.26794/2587-5671-2019-23-1-27-37 


\section{INTRODUCTION}

With "Infrastructure Project Finance", we will be dealing with a large, current topic in a comprehensive overall context ${ }^{1}$. "How to break into the Top Five of the World Economy": This year's topic of the Fifth International Financial University Forum (2018) is reminiscent of a great turnaround in Russian history in the late 17th century. Tsar Peter the Great took extensive reforms that changed Russia from a medieval country into a leading European state.

Of course, today's world is different. The world economy is considered as the international exchange of goods and services expressed in monetary units of account. The goal to "break into the Top Five of the World Economy" sounds ambitious. Models and valuations of the world economy vary widely (e.g., GDP nominal per capita or GDP purchasing power parity). Accordingly the rankings differ, but among the leading economies generally are the US, China, Japan, Germany and the European Union (of 28 member states with a single internal market).

We should remember change as being a constant element. China and India having dominated the global output, Europe and North America took over global leadership in the 19th century through the Industrial Revolutions: the story of the rise and fall of great powers [1,2]. And we know of course, times again are changing dramatically with the so-called "Industry 4.0 " - the digital revolution.

\section{INTERNATIONAL INVESTMENT}

\subsection{Basics: Infrastructure Project Finance}

This puts us in the middle of international investment, because change and growth need capital. That means financing, the focus here being on project financing. Project financing takes place internationally [3]. It is a global phenomenon, complex and multifaceted [4]. Investors aim for profit. The participants come together for the project entrepreneurially as a venture community (German: Wagnisgemeinschaft) [5].

Project financing is traditionally located in infrastructure projects. Private financing of the extraction of natural resources (e.g., oil, gas, ores) seems to be attractive. There is also a tradition for this in Russia. Mention may be made, e.g., of the development of Russian oil fields already around 1880 , financed by the French Crédit Lyonnais. Private or - combined - public projects (so-called public private partnerships) are legion around the world. We enter a global field that

${ }^{1}$ Extended version of my presentation at the Fifth International Financial University Forum, Moscow, on November 28, 2018. includes transnational investment (free trade) and legal order (rule of law). In practice, there are considerable, mostly infrastructural projects that serve basic needs (common good). Famous examples include the construction of the Suez Canal (Egypt, 1869), the capital Brasilia (Brasil, 1960), the Eurotunnel between France and England (1993) as well as the gas pipelines from Russia to Germany (Nord Stream, 2011/2019).

The rule of law enforces minimum standards of fairness, both substantive and procedural: all persons and authorities, whether public or private, should "be bound by and entitled to the benefit of laws publicly made, taking effect (generally) in the future and publicly administered in the courts" [6]. The issue is crossborder, transnational cooperation - project-related in the form of a venture community. As Aristotle already said: "No human community can exist and succeed without law" [7], which also transnationally establishes the necessary trust. That is why I am talking about Intercultural Project Finance. Let us look at the even larger picture first: Eurasia.

\subsection{Infrastructure Networks: China's "Road and Belt"-Strategy}

The One Belt One Road (OBOR), also referred to as the Silk Road Economic Belt: This is a strategy adopted by the Chinese government (Communist Party of China) involving infrastructure development and investments in some 60 countries in Europe, Asia, Oceania and Africa. They are to be connected in a geographically structured way by the overland routes ("one road") or the sea routes ("one belt"). That will cost an estimated US \$4-8 trillion.

In fact, President $X i$ Jinping is thereby building an economic area across four continents with 5 billion people "for global economic development in the new world order" [8]. In late 2017, at the Communist party congress, he proclaimed a "socialist rule of law" and a global era for "Chinese-style socialism" that has made China a great power [9]. In concert with his initiative for digitization (so-called “Digital Silk Road") Xi Jinping wants to take over the leadership in the global economy by 2025 .

\subsection{Focussing on Russia: German and European Perspectives (Eurasia)}

Keeping this in mind, I would like to focus on Russia, Germany and the European Union. This Eurasian perspective is obvious. Marco Polo described it as a commercial traveler to the court of the Mongolian Kublai Khan, Emperor of China, in his famous book "Il Milione” (The Travels of Marco Polo - Книга чудес света) as early as the 13 th century. 
With Eastern Europe and Russia, Eurasia covers Central Asia via the Silk Road and stretches from the west to the east all the way from the Atlantic to the Pacific - literally from Lisbon to Vladivostok. In terms of resources, technical know-how and financial strength for economic growth, this is probably the (only) way in the long run to master the Chinese challenge in peaceful sustainable development.

\section{CONNECTING EUROPE AND ASIA (EURASIA)}

\subsection{The European Union-Strategy}

In September 2018, the European Commission and the High Representative of the European Union for Foreign Affairs and Security Policy adopted a Joint Communication that sets out the European Union's vision for a new and comprehensive strategy to better connect Europe and $\mathrm{Asia}^{2}$. This can be understood as a groundbreaking milestone to build "an ever closer union among the peoples of Europe" (article 1(2) Treaty on European Union) and to "develop a special relationship with neighbouring countries, aiming to establish an area of prosperity and good neighbourliness, founded on the values of the Union and characterised by close and peaceful relations based on cooperation" (article 8(1) Treaty on European Union).

The Joint Communication builds on the European Union's own experience of enhancing connections between its Member States (incl. "Brexit"), with and in other regions. Including free-trade agreements like the Comprehensive Economic and Trade Agreement (CETA) with Canada, and the Japan-EU Free Trade Agreement (JEFTA); this comprises approx. 30\% of the world GDP ( $40 \%$ of world trade), thereby establishing the strongest economic area in the world at the beginning of 2019. With Russia, Central Asia and China the route may therefore lead from Lisbon to Tokyo. This shows the dimension of the EU initiative for Europe and Asia. With sustainable, comprehensive and rules-based connectivity at its core, the Communication will help to guide the European Union's external action in this field and is part of the implementation of its Global Strategy. I will highlight key aspects of that strategy as a tool to set the floor for better cooperation with Russia especially for projects of intercultural project financing.

\footnotetext{
${ }^{2}$ Joint Communication, 19.09.2018. URL: https://eeas.europa eu/headquarters/headquarters-homepage/50752/europeanway-connectivity-\%E $2 \% 80 \% 93$-new-strategy-how-betterconnect-europe-and-asia_en (accessed on 08.01.2019); Joint Communication, 20.09.2018. URL: https://eeas.europa.eu/ headquarters/headquarters-homepage/50792/european-wayconnectivity-\%E 2\%80\%93-new-strategy-how-better-connect-europe-and-asia_en (accessed on 08.01.2019).
}

So, first of all, what is Connectivity? - Connectivity is the way to the future, the strategists of the European Union point out. The more connected we are, the more opportunities we have - to find common political solutions and to bring economic prosperity to citizens. Vice-President of the European Commission, Federica Mogherini, said: "Our approach is the European Union's way: to establish stronger networks and strengthen partnerships for sustainable connectivity, across all sectors and based on a respect for common rules $(. .$.$) - to tackle challenges and take opportunities,$ to the benefit of people in Europe and in Asia as well." ${ }^{3}$

Common rules, that means, common standards, e.g. in technical terms, and as I have put it: rules of law, which basically transnationally establish the trust necessary for succeeding in joint activities of intercultural project finance [10]. This sets the field for the economic and social development, i.e. for prosperity in Eurasia. Let us first take a look at European cornerstones.

\subsection{Three Core Approaches for Implementation}

How will the European Union enhance connectivity? - The European Union will combine a principled approach to connectivity and the recognition - quite in the sense of our approach of intercultural project finance - that Asia encompasses different regions, which are home to very diverse countries in terms of economic models and level of development. It is a matter of concrete actions, based on three strands: ${ }^{4}$

1. Creating transport links, energy and digital networks, and human connections: Efficient infrastructure and connections create growth and jobs and enable people and goods to move. From transport links to energy networks, people-to-people contacts to digital webs, the European Union will extend its own networks and contribute to new ones beyond its borders. The European Union's Trans-European Transport Networks are to be connected.

The Union's digital single market, strategists say, provides a blueprint for enhancing trade in digital services, while its Digital4Development strategy ${ }^{5}$ fosters socio-economic development: "We will share our experience of creating regional, liberalised energy markets with a focus on market-driven transformation towards clean energy. We will continue to promote human exchanges and mobility, for example in education, research, innovation, culture and tourism."

\footnotetext{
${ }^{3}$ Joint Communication, 20.09.2018 (footnote 2).

${ }^{4}$ Footnote 3.

${ }^{5}$ EU-Commission, 04.05.2018. URL: https://ec.europa.eu/europeaid/news-and-events/european-commission-presentsstrategy-mainstream-digitalisation-eu-development_en (accessed on 08.01.2019).
} 
2. The second strand is offering connectivity partnerships to countries in Asia and organisations: Our world depends on the smooth and secure flow of goods, services and people. The European Union with a track record of a rules-based, fair and transparent internal market, so strategists emphasise, is engaging with partners beyond its borders in order to promote similar approaches to sustainable connectivity. This comprises the instruments of bilateral co-operations and agreements as well as multilateral perspectives and community (see 3.1).

The strategy has a global dimension. The European Union will pursue bilateral connectivity partnerships, also, e.g., in existing frameworks like ASEAN (Association of Southeast Asian Nations), the World Trade Organisation (WTO), the International Energy Agency (IEA), the International Maritime Organisation (IMO) and the United Nations - in order to establish sustainable and fair global practices. Comprehensive thinking and acting is required. It is basically a matter of intercultural competence and concepts for the practical implementation (see 4).

3. And the third strand of the new European Union strategy, as the necessary as well as common basis of any connectivity, is: promoting sustainable finance through utilising diverse financial tools. This includes our field of intercultural project finance, highlighting its paramount significance for society as a whole regarding development and prosperity in the Eurasian region from Lisbon to Vladivostok and Tokyo. As Jyrki Katainen from the EU-Commission said: ${ }^{6}$

"We want to work with our Asian partners to improve connections between Europe and Asia, while bringing our values and approach in doing so. Infrastructure networks that will be built should be coherent, interoperable, as well as financially and environmentally sustainable. Calls for tender should be open and transparent to promote good governance and a level playing field."

\subsection{Dimensions}

This means we are dealing with a gigantic field. With Asia alone requiring an estimated $€ 1.3$ trillion per year for infrastructure investment, there are significant opportunities for companies from the European Union, Russia and other countries from our Eastern neighbourhood; as well as from the Western Balkans and around the globe. - Provided that robust legal frameworks are in place [11].

\footnotetext{
${ }^{6}$ Vice-President for Jobs, Growth, Investment and Competitiveness, 19.09.2018. URL: http://europa.eu/rapid/press-release_IP-18-5803_en.htm (accessed on 08.01.2019).
}

\section{TRUST: BASICS OF INTERCULTURAL PROJECT FINANCE}

\subsection{Robust Legal Frameworks}

But how about "robust legal frameworks"? - The European Union is talking about financing connectivity internally and externally through combining innovative financing initiatives and creating opportunities for private sector participation. And of course, there is help in place, e.g. the European Fund for Strategic Investment (EFSI), established by the European Investment Bank (EIB) for medium-sized companies and projects; ${ }^{7}$ the European Neighbourhood Instrument (ENI), the financial component of the European Neighbourhood Policy, also fosters the relations with Russia $^{8}$. What is generally needed is an adequate system of an international investor protection law.

The foundation comes from international treaties, e.g. German agreements on the promotion and reciprocal protection of capital investments with Russia and China9. They set the rules for arbitration in the relations between private investors and the state (Investor State Dispute Settlement, ISDS) and lead to the International Centre for Settlement of Investment Disputes (ICSID), which more than 150 states are members of ${ }^{10}$. Predominantly, the parties to the dispute may - like among private investors - agree on an ad-hoc arbitral tribunal according to the rules of the United Nations Commission on International Trade Law (UNCITRAL): The UN Convention on the Recognition and Enforcement of Foreign Arbitral Awards (1958) provides legal protection with the principle of equal treatment of nationals (Art III UNÜ).

New structures are evolving. China is institutionally building an alternative network, e.g., with the Asian Infrastructure Investment Bank (AIIB, Beijing) also supported by Germany and Russia: ${ }^{11}$ The multilateral development bank, founded in 2015, is to invest in sustainable infrastructure and other productive sectors. China wants to form its own investment protection mechanism with arbitral courts, along with its new silk roads ("Belt and Road Courts") ${ }^{12}$. The European Union is to establish

\footnotetext{
${ }^{7}$ For more information: European Investment Project Portal (EIPP). URL: https://ec.europa.eu/eipp/desktop/en/index. html?2nd-language=en (accessed on 08.01.2019).

${ }^{8}$ See of 27.12.2018. URL: https://www.euneighbours.eu/ru/ policy/evropeiskii-instrument-sosedstva-eis (accessed on 08.01.2019).

${ }^{9}$ Of 24.04.1990, Bundesgesetzblatt (BGBl, Germany) II S 342 (USSR) and 13.01.1992, BGBl II S 1016 (Russia); 01.12.2003, BGB1 2005 II S 732 (China).

${ }^{10}$ See URL: icsid.worldbank.org (accessed on 08.01.2019).

${ }^{11}$ For details. URL: https://www.aiib.org/en/index.html (accessed on 08.01.2019).

${ }^{12}$ See above 2.2 and Dezan Shira Assoc. URL: https://www. silkroadbriefing.com/news/2018/01/24/china-passes-belt-
} 
a multilateral Court for the Settlement of Investment Disputes ${ }^{13}$. A complex core area of further development.

\subsection{Practical Aspects}

In general, practical experience from a lawyer's point of view shows: Due diligence in project finance is, around the globe and in practical terms, the cornerstone and starting point. It is a matter of trust building, quite in the sake of self-interest by taking responsiblity (see 6.3) [12]. Due diligence is the responsibility of each party involved in the development of a financing project with the assistance of their counsel. Regarding the individual case, different factors and considerations are taken into account depending on the relevant circumstances. Generally, five basic aspects are highlighted: ${ }^{14}$

1. Language Barriers, because of the interconnectedness of our economies (project finance lawyers and local attorneys, translations by non-lawyers);

2. Understanding of foreign legal systems, because of differences between common law system and civil law system or, e.g., the dimensions of Islamic banking and finance (drafting contracts and tax structure of the project, collaboration between project finance lawyers and local attorneys);

3. Ethical Issues, because of different rules and understanding of ethics according to the different cultures of people participating within the venture community of the project (which is why we talk about intercultural project finance! - See 2.1).

4. Time Zone, because project finance transactions commonly involve parties around the world and communication among parties from different time zones are difficult;

5. Interests of Lenders Involved, because it is common for a large project finance transaction to involve lenders from different sectors (commercial banks, quasi government banks, other institutions and individuals) with different interests. Some lenders might want to invest more than others, some are willing to take more risks and some might have different viewpoints on the same issues concerning the project: Out of all this, the venture community has to be formed contractually.

Altogether, those issues are complex, more or less culturally driven, and might be time consuming to

road-trade-dispute-mechanism-will-final-say/ (accessed on 08.01.2019).

${ }^{13}$ See Negotiating Directives of the Council of the European Union, 12981/17 (ADD 1 DCL 1), 20.03.2018. URL: http://data. consilium.europa.eu/doc/document/ST-12981-2017-ADD-1DCL-1/en/pdf (accessed on 08.01.2019).

${ }^{14}$ Henri Nkuepo. URL: www.linkedin.com/pulse/ 20141004164529118653306 (accessed on 08.01.2019). resolve. Easy paths are rare where, as in this case, it is in fact new terrain that is to be developed. That is why, e.g. some African states prefer financing infrastructure projects with Chinese loans. The situation is confusing. But at the end of the day they might pay heavily on unilateral connection; more and more people seem to be realising this ${ }^{15}$.

\subsection{European Perspectives}

So, better let us stay with the European Union and its prinicples-based approach formed with fundamental values such as liberty, democracy and rule of law: The European Union, according to the Joint Communication (see 3.1), will look to combine financial sources (capital for investment purposes) from international financial institutions, multilateral development banks and the private sector to ensure sustainable domestic and international finance for connectivity, while ensuring transparency and a level playing field for businesses. - Agreed.

In fact, the involvement of the private sector seems to be largely lacking. Decisive probably, because there is no or no sufficient robust legal frameworks. Government actors (institutions) are widely dominating the field. Co-operations with private investors may develop new fields. As the European Union put it in its strategy, the "potential for additional intelligent, innovative and multi-dimensional investment financing" in and towards Asia is significant ${ }^{16}$. This also applies to the demand.

How can the potential be realized? - Namely, e.g. with Russia's New High Speed Train, which can develop Russia in the direction of Asia, while forging link with the Western European fast train network, and corresponding projects (logistic centres, internet and artificial intelligence). The European Union points out its "comprehensive approach to investment financing, pioneered in Europe by the European Fund for Strategic Investments ${ }^{17}$, as well as outside the European Union through specific geographical investment facilities".

According to the European Union this means having successfully leveraged investments for infrastructure and

\footnotetext{
${ }^{15}$ See, e.g., Nick van Mead, 31.07.2018. URL: https://www. theguardian.com/cities/2018/jul/31/china-in-africa-win-windevelopment-or-a-new-colonialism (accessed on 08.01.2019). Aubrey Hruby, 04.09.2018. URL: https://www.weforum.org/ agenda/2018/09/three-myths-about-chinas-investment-inafrica-and-why-they-need-to-be-dispelled/ (accessed on 08.01.2019). For more material. URL: http://www.chinaafricarealstory.com/2018/ (accessed on 08.01.2019).

${ }^{16}$ EU-Commission, 19.9.2018. URL: http://europa.eu/rapid/ press-release_IP-18-5803_en.htm (accessed on 08.01.2019).

${ }^{17}$ See preceding footnote.
} 
connectivity. This is to be combined with the European Commission's proposals for reinforced external action under the next European Union Multi-annual Financial Framework (2021-2027). - Here, we can (only) set some landmarks for further investigations on this huge field.

\subsection{Project Finance: Structure}

First to the basic structure of Project Finance. One of the primary advantages of project financing is that it provides for off-balance-sheet financing of the project, which will not affect the credit of the shareholders or the government contracting authority. In fact it shifts some of the project risk, usually a significant share, to the lenders in exchange for which the lenders obtain a higher margin than for normal corporate lending; in terms of valuation, hopefully an appropriate margin (see 4.5).- The typical project financing structure (so-called plain vanilla") for a build, operate and transfer (BOT) project, according to the World Bank, is shown here (Fig. 1).

The World Bank describes ${ }^{18}$ key elements of the structure as following:

1. The Special purpose vehicle (SPV) is the project company with no previous business or record [13]. The sole activity of the project company is to carry out the project; in order to do that, this company (the SPV) subcontracts most aspects through construction contract and operations contract.-Overall, the said venture community constitutes itself in this way (see 2.1).

2. For new building projects, such as the larger infrastructure projects mentioned as examples, there is no revenue stream during the construction phase. That means: debt service will only be possible once the project is on line during the operations phase; the sole revenue stream is likely to be under an offtake or power purchase agreement. - Therefore, parties within the venture community, depending in particular on their contractual circumstances, take significant risks during the construction phase.

3. And in terms of liability: There is limited or no recourse to the sponsors of the project. Shareholders of the project company (SPV) are generally only liable to the extent of their shareholdings. - This is an important perspective and basis of evaluation for the other members of the venture community.

\subsection{Project Finance: Measurement}

The most important aspect, however, is missing in its fundamental significance. The fact that the pro-

\footnotetext{
${ }^{18}$ See URL: https://ppp.worldbank.org/public-private-partnership/financing/project-finance-concepts (accessed on 08.01.2019).
}

ject remains off-balance-sheet for the sponsors and for the host government, points to this indirectly. However, this does not do justice to its importance in practice and theory. Clearly, any project structure seeking off-balance-sheet treatment needs to be considered carefully under the applicable law (national and/or international law, contract).

However, this first and foremost encompasses the applicable accounting rules, i.e. the standards for recognition and measurement. For basically, for the investors and the investments it is a matter of the value ratios: Who profits from the added value gained with the projects? With the balance treatment (valuation) a substantial risk may be - more or less transparently - shifted to the lenders. In a nutshell, this means: In practice, the valuation (rating) of the project - its assets - is the key for the establishment and the sustainable success of the project.

\section{COMPARATIVE PERSPECTIVES OF INTERCULTURAL PROJECT FINANCE}

\subsection{Investment Protection Law Interculturally}

This points to the need to establish an internationally strong legal protection system for an international Order of Assets (German: Vermoegensordnung) [14]. That includes - in the coordination of international and private law - good rules for investment in general [15]. In individual cases like project finance, this means the concrete contractual coordination and faithful implementation in practice. And ultimately, it means the enforcement of rights (for example, appropriate valuation and compensation) by state or private institutions (courts, arbitration). This is based on independence, neutrality and fairness ("fair and equitable treatment"). Fundamental are freedom of contract and the freedom of capital transfer.

This is based on reciprocity as an adequate multijurisdictional approach. It is about compliance with international standards and agreements, which is crucial for project practice. To not apply a law is, says Aristotle, as if it had not been made. This also applies universally to contracts. The challenge arises of meaningful coordination for transnational investment between national, supranational and international statehood and the private sphere. The reinforcement - and at the same time preservation of human society through rights (duties) ensures the balance: A society works best when everyone respects their rights and works towards compliance (and in the last instance: sanctioning). This also applies to those involved in project financing within a venture community. 


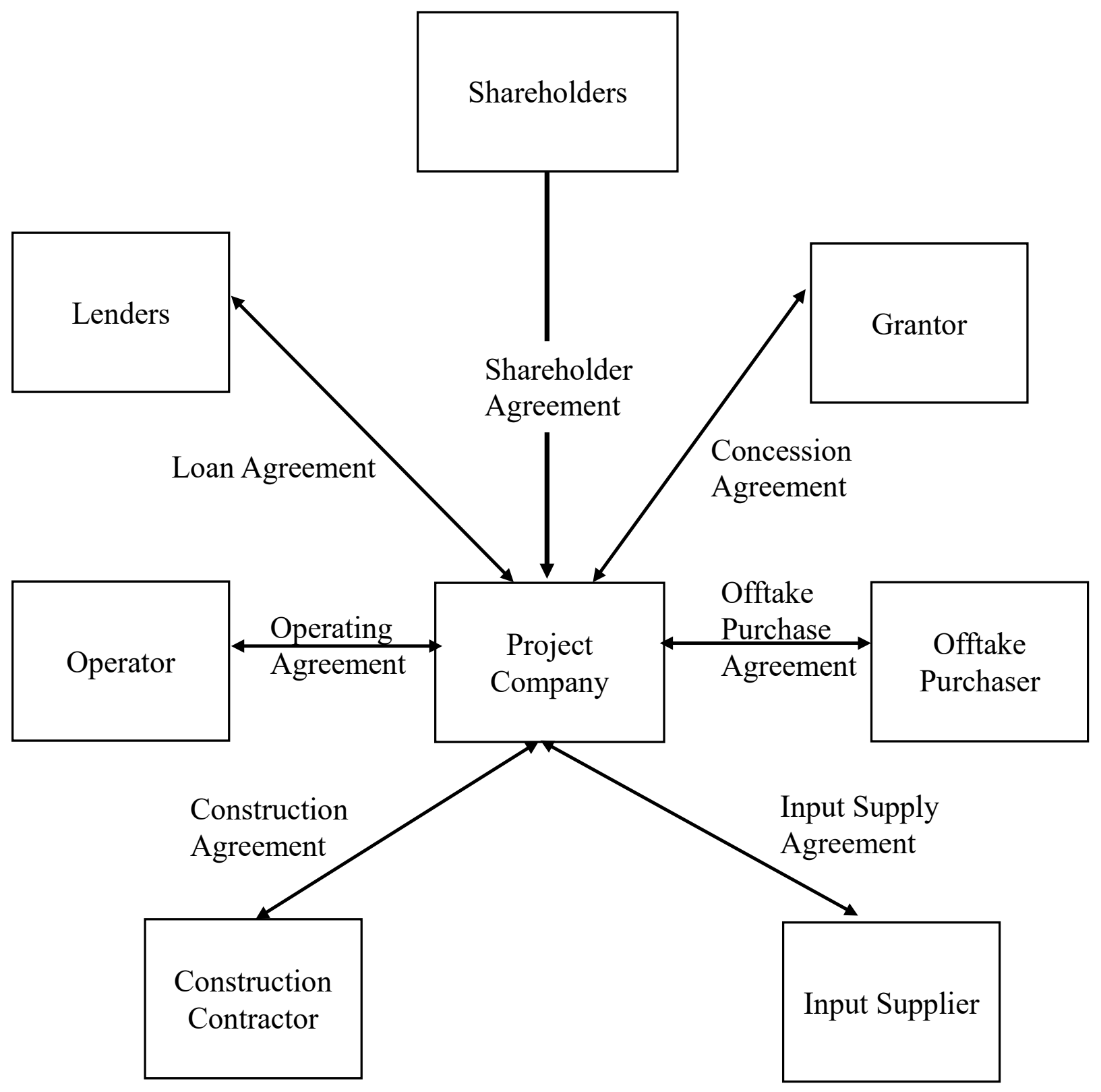

\section{Fig. 1. Typical project finance structure}

Source: World Bank Group, New York. URL: https://ppp.worldbank.org/public-private-partnership/financing/project-finance-concepts (accessed on 08.01.2019).

\subsection{Content: Substance over Form}

What is decisive is the content of a global system of assets as well as for project financing in concrete terms: Both are to establish the idea of justice in the rule of law (see 2.1), and thus sustainable prosperity and peace. It should not be about empty phrases, but about a comprehensive view of the substance in terms of valuation law. - I lectured here last year at the conference on this key issue (banking on trust) in the light of the so-called global financial crisis.

And this crisis continues because the causes are still not resolved. This is proven by massive manipulations and the ongoing debt crisis worldwide with worthless financial instruments and companies with massively manipulated balance sheets - thanks also to cruel central banks policies. - But, as is the case here entrepreneurially, who is interested in projects that have no solid substance? - Guidance may come for humans and business alike from the wisdom of Confucius, who similarly says: "Only he for whom form and content are in balance is a noble person [16]."

\subsection{Evaluation and Structuring of Projects}

Essentially, all parties involved are concerned with evaluation issues and, even for possible dispute resolution, a strong law of evaluation. As with any 
well-managed company, this encompasses the sustainable planning and monitoring of the project (country-specific risk analysis, liquidity, internal audit) as well as a system of sustainable evaluation of project investments and assets, including the financial and earnings situation of the project (in terms of valuation and accounting, id est, proper appraisal and financial reporting). The project evaluation is based on the principles of business valuation, international and/or contractually agreed upon.

Well, this is a broad field that still requires a lot of comparative work internationally. Remember the wisdom of Fyodor Mikhailovich Dostoevsky. He describes the Russian reality as a sublime, universal, ordered chaos. - But who can judge that, especially if he is a foreigner? - In particular in terms of legally valid evaluation! - In any case, Dostoevsky shows us with his "Idiot" (Идиот from 1868/69) that chaos, though destroying human order, belongs to every new orientation [17]. And remember, we are in the middle of a huge change worldwide.

\section{TRUST CONCEPT OF INTERCULTURAL PROJECT FINANCING}

\subsection{Focussing Transnationally}

The world is being rearranged. International capital markets, in which huge sums of private capital are transferred around the globe every day, also change the landscape for intercultural project finance. It is not a matter of colourful financial instruments (paper values) and questionable prognostications (hope values), but of substantial contract patterns and transnationally tenable framing conditions for investments. Investment protection has to be developed in legal comparison globally through private and international law (see 5). Therefore, we need to come up with sustainable legal structures to tap on the global capital market for infrastructure project finance in Eurasia.

All in all, what should be emphasised is this: no human community can exist without law (rule of law). This applies in private relations as well as to peoples in the global community of states and alliances, in particular also to economic development - as here for the community of private and state investors in intercultural project finance (venture community). For Europe, this was set down groundbreakingly in the Charta of Paris in 1990 after the peaceful revolutions in Poland, Russia and Germany with the fall of the Berlin Wall: "The free will of the individual, exercised in democracy and protected by the rule of law, forms the necessary basis for successful economic and social development." ${ }^{19}$ More than thirty states, including Canada, Germany, Russia and the United States, have signed that Charter for a New Europe.

What is fundamental as well as expedient is the formation of trust among those involved in project financing (again: banking on trust!). They generally come together from different cultural spheres to form a venture community. This underlines the importance of my conceptualization of "intercultural project finance". That is the expression of a commonly established order. It promotes general prosperity and is established in legal comparison as an order of assets. Its content is closely linked to the global financial and monetary order, especially as in intercultural project finance there are usually different currency areas involved.

\subsection{The Trust Concept Internationally}

I have devised my "Trust Concept of Intercultural Project Financing” (Fig. 2) as a basis for practice and further elaboration. Characteristic of an intercultural project is a transnational, common goal of the venture community. In our field, this is the successful creation and sustainable operation of the concrete infrastructure project. First of all: To achieve this goal, appropriate funding is needed. Intercultural projects require long-term investment (capital). So the basis is a comprehensive concept of trust founded on legal norms and legal protection in practice.

The requirement of long-term finance builds on what holds traditionally in the banking domain in the relationship between creditor and debtor: "Capital is money plus trust." - For as a rule, it is about other people's money [18]. This is the basis for entrepreneurial action. Here, the project financiers entrust those people with the capital responsible for the creation and operation of the project. This leads to responsibility, i.e. accountability and possibly also liability claims. What is needed are reasonable, innovative and just forms of participation in chances (profit) and risks (losses) - in order to prohibit unreasonable transfer of wealth (see 4.5 and 6.3).

Overall, it is therefore a matter of substance, i.e. real values. In the second step, we may thus make the general principle of banking practice as follows: Capital is "money plus trust in real values". - In comparison to hypothetical forecast games of short-term speculation (the so-called "numbers game"), the mentioned aspect of "substance" gains considerable scope: it is about the investment of intelligent investors in contradistinction to "speculators" [19]. The project financiers are inves-

\footnotetext{
${ }^{19} 1$ st section of the Charta of Paris, of 21.11.1990, following the Helsinki Final Act, Conference on Security and Co-operation in Europe, of 01.08.1975.
} 


\section{Trust Concept of Intercultural Project Financing}

\section{Characteristic of an intercultural project is a transnational common goal}

\section{Basic assumptions for practice:}

Thesis 1: Intercultural projects require long-term investment (capital)

Thesis 2: Capital is "money plus trust in real values"

Thesis 3: Trust is established by common standards (valuation, accounting and contractual rules) and their faithful execution (if applicable, sanctioning)

\section{Global Financial Markets}

\section{Fig. 2. The Trust Concept of Intercultural Project Financing}

Sources: presentation of the author.

tors in long-term projects, not speculators in shortterm gains. They are looking for real values to build on. That "substance" is characterised by the attachment to tangible assets - that means: real assets like natural ressources (oil, gas, ores) and technical know-how instead of fancy financial instruments (paper values).

And, thirdly, along with this: Trust is based on personal confidence. This stems from and is permanently secured through clear legal norms among the persons and institutions involved in financing the project. This requires clear legal foundations (rules of international law and individual contract), creating sustainable trust. That means: Trust is established by common standards (valuation, accounting and contractual rules) and their faithful execution (if applicable, sanctioning through effective legal protection - dispute settlement).

\subsection{International Order of Assets through Valuation Law}

In this sense, I have developed a general concept for the evaluation of assets [20,21]. As in all life circum- stances, it is a matter of adequate valuation. Overall, for peace, development and general prosperity we need an internationally adequate order of assets. The material nucleus of any order of assets is the following: What is valued as "assets" in what way is determined by the law, id est, specifically valuation law (in the domain of corporations termed accounting law or, synonymously, financial reporting). In this context it is essential to remember that it is we ourselves that are the source of value: "The value of values comes from valuers, and not the reverse" [22]. It is a matter of responsibility.

All in all, this is to prevent the assets situation - in general of the corporation or, as here, the infrastructure project (SPV; see 4.4) - being represented as too good (i.e. too valuable) or too bad (i.e. too worthless). At the same time, the legally bound valuation prevents illegitimate transfer of assets (valuables) between, e.g., majority and minority financiers (shareholders) or between equity financiers (shareholders) and debt financiers (bondholders). This is an expression of the 
constitution of liberty, in which the economic and legal order is an order of assets (German: Vermoegensordnung): Specific assets are each attributed to a legal subject (natural person or juridical person, SPV; see 4.4) and are dealt with in business, i.e. contractually.

Altogether, it is a matter of the suitable balance of interests among those involved in the infrastructure projects. As already set down in Roman law, in practice it is the natural principle that holds contractually: "I give so you may give" (Latin: do ut des). The concept of trust therefore builds materially and formally on the imperative of truth and the requirements of the civil process: In order to ensure that the evaluation questions can be resolved sustainably in practice, that means verifiably. It is about the actual conditions (facts), the value-forming properties of the project. In this way only the necessary trust between a (project) company and its investors can be established.

This may result in joint project success: The persons involved can reach both their personal goal (selfinterest) as well as the common goal. Along with the success of the infrastructure project this serves the common overall good. We here see the principle of the "invisible hand", described generally already by Adam Smith [23]. For practice to work, valuation law is also needed. In depth information on this topic can be found in my article "Legal Requirements for the Proper Appraisal of Companies: A Substantive Civil-Procedural Concept" [20]. - Basically, what is at work here is the requirement of faithfulness between humans, along with the mentioned imperative of truth in valuation and a strong procedural verifiability (legal protection).

\section{CONCLUSION AND OUTLOOK}

Rethinking is necessary. The world is changing from a unilateral structure of leadership (Pax Americana) to multipolarity. That is what global experience demands in the light of the global financial crisis (Stiglitz: "the great American robbery") [24]. The theme of this year's forum emphases this as a goal. What is needed are suitable concepts. The perspective of an Anglo-American practice of so-called "international project finance" require the development to an interculturally oriented community. How do marketbased individualism and aspects of state planning go hand in hand? What about transfer of risk and profit sharing? - In legal comparison, a comprehensive concept of trust can form the basis interculturally.

Overall we need a general investment law for a global order of assets. Interculturally, it is not just any, but good rules and regulations and trusted practice that are required, i.e. adequate law for investments. In particular, the judicial practice is a 'litmus test' for the degree of development of a state and its protection of human rights [25]. As with corporate finance and governance, intercultural in the realm of project financing transnationally means: "banking on trust in real values". It is about adequate balance of interest, about the Doctrine of the Mean: sustainable substance all round instead of empty forms ("substance over form"), here for the venture community for intercultural project finance. Practically in terms of implementation that means:

1. Universal capital of trust (Encounter);

2. Intercultural competence development (Education);

3. Conceptual project design (Consulting).

Consider this: China is already establishing new structures and standards of financing, e.g. with a goldbacked Yuan (so-called Gold Trade Notes) around the world in order to challenge the global monopoly of the US (Petro) Dollar and the existing world of global finance. The financial world is in transition. It is about peace [26]. This changes the perspectives for infrastructure project finance in a fundamental way. The future belongs to intercultural investment. - Should we watch as others dominate the business and set the new standards worldwide? - Reason with the principle of reciprocity may peacefully maintain the balance in the progress for general prosperity.

\section{REFERENCES}

1. Kennedy P. The rise and fall of the great powers: Economic change and military conflict from 1500 to 2000 . New York, NY: Vintage Books; 1987. 678 p.

2. Le Goff J. L’Europe est-elle née au Moyen Age? Paris: Editions du Seuil; 2003. 344 p.

3. Esty B.C. Why study large projects? An introduction to research on project finance. European Financial Management. 2004;10(2):213-224. DOI: 10.1111/j.1354-7798.2004.00247.x

4. Mueller J. International project finance: Review and implications for international finance and international business. Management Review Quarterly. 2017;67(2):97-133. DOI: 10.1007/s11301-017-0125-3

5. Luttermann C. Unternehmen, Kapital und Genußrechte: Eine Studie über Grundlagen der Unternehmensfinanzierung und zum internationalen Kapitalmarktrecht. Tübingen: J.C.B. Mohr/Siebeck; $1998.595 \mathrm{p}$.

6. Bingham T. The rule of law. London: Penguin Books; 2011. 213 p. 
7. Aristotle The politics. London: Penguin Classics; 1981.508 p.

8. Xi J. China regieren. Beijing: Verlag fuer fremdsprachige Literatur; 2014.576 p.

9. Marshall D., ed. The international rule of law movement: A crisis of legitimacy and the way forward. Cambridge, MA: Harvard Law School; 2014. 308 p.

10. Luttermann C., Hummel D. Interkulturelle Projektfinanzierung: Vertrauenskonzept, eurasische Perspektiven und Rechtspraxis. Recht der Internationalen Wirtschaft (RIW). 2018;64(1-2):30-37.

11. Luttermann C. German and Russian Direct Investment under the Rule of International Law. Zeitschrift für Internationales Wirtschaftsrecht (IWRZ). 2015;1(1):90-95.

12. Luttermann C. Banking on trust as individual responsibility: Corporate finance, speculation and global capital markets. In: Du Plessis J.J., Grossfeld B., Luttermann C. et al. German corporate governance in international and European context. $3^{\text {rd }}$ ed. Heidelberg, New York: Springer-Verlag; 2017:431-475.

13. Berle A.A. Studies in the law of corporation finance. Chicago: Callahan and Co.; 1928. 199 p.

14. Luttermann C. Corporate law and the Vermoegensordnung (order of assets). European Business Law Review (EBRL). 2015;26(1):31-48.

15. Luttermann C. Über Idee und Methodik eines internationalen Investitionsschutzes (Vermögensordnung) durch Privatrecht und Völkerrecht. Zeitschrift für Europarecht, Internationales Privatrecht und Rechtsvergleichung (ZfRV). 2015:56(6):274-282.

16. Confucius. The Analects (Lun yü - 206 BC-220 AD). London: Penguin Classics; 1979. 256 p.

17. Dostoevsky F.M. The Idiot. Russkii vestnik. 1868-1869. (In Russ.).

18. Brandeis L.D. Other people's money and how the bankers use it. New York, NY: F.A. Stokes Co. Publ.; 1913. 223 p.

19. Graham B. The intelligent investor: A book of practical counsel. New York, NY: HarperCollinsPublishers; $2003.623 \mathrm{p}$.

20. Luttermann C. Legal requirements for the proper appraisal of companies: A substantive civil-procedural concept. In: Du Plessis J.J., Grossfeld B., Luttermann C. et al. German corporate governance in international and European context. $3^{\text {rd }}$ ed. Heidelberg, New York: Springer-Verlag; 2017:401-430.

21. Luttermann C. Juristische Anforderungen an eine ordnungsgemaesse Unternehmensbewertung und an ein Bewertungsgutachten. In: Petersen K., Zwirner C. Handbuch Unternehmensbewertung. $2^{\text {nd }}$ ed. Köln: Bundesanzeiger Verlag; 2017:609-637.

22. Korsgaard C.M. The dependence of value on humanity. In: Raz J. The practice of value. Oxford: Clarendon Press; 2003:63-85. (The Berkeley Tanner Lectures Series).

23. Smith A. An inquiry into the nature and causes of the wealth of nations. $1^{\text {st }}$ ed. London: W. Strahan and T. Cadell; 1776.

24. Stiglitz J.E. Freefall: America, free markets, and the sinking of the world economy. New York, NY: W.W. Norton \& Co.; 2010. 443 p.

25. Kuznetsov V.I., Tuzmukhamedov B. R. International law: A Russian introduction. The Hague: Eleven International Publ.; 2009. 720 p.

26. Erasmus (of Rotterdam) Querela pacis. Basel: J. Froben; 1517.70 p.

\section{ABOUT THE AUTHOR}

Claus H. Luttermann - Dr. Sci. (Law), Full Professor, Chair for Civil Law, German and International Commercial Law and Business Law, Faculty of Economics (Vice Dean em.), Catholic University of EichstaettIngolstadt, Ingolstadt, Germany

claus.luttermann@ku.ei

\section{ИНФОРМАЦИЯ ОБ АВТОРЕ}

Клаус $\boldsymbol{X}$. Люттерманн - доктор юридических наук, профессор кафедры гражданского права, немецкого и международного торгового права и предпринимательского права, экономический факультет (заместитель декана), Католический университет им. Айхштетт-Ингольштадт, Ингольштадт, Германия claus.luttermann@ku.ei

The author read and approved the final version of the manuscript. Автор прочитал и одобрил окончательный вариант рукописи. 